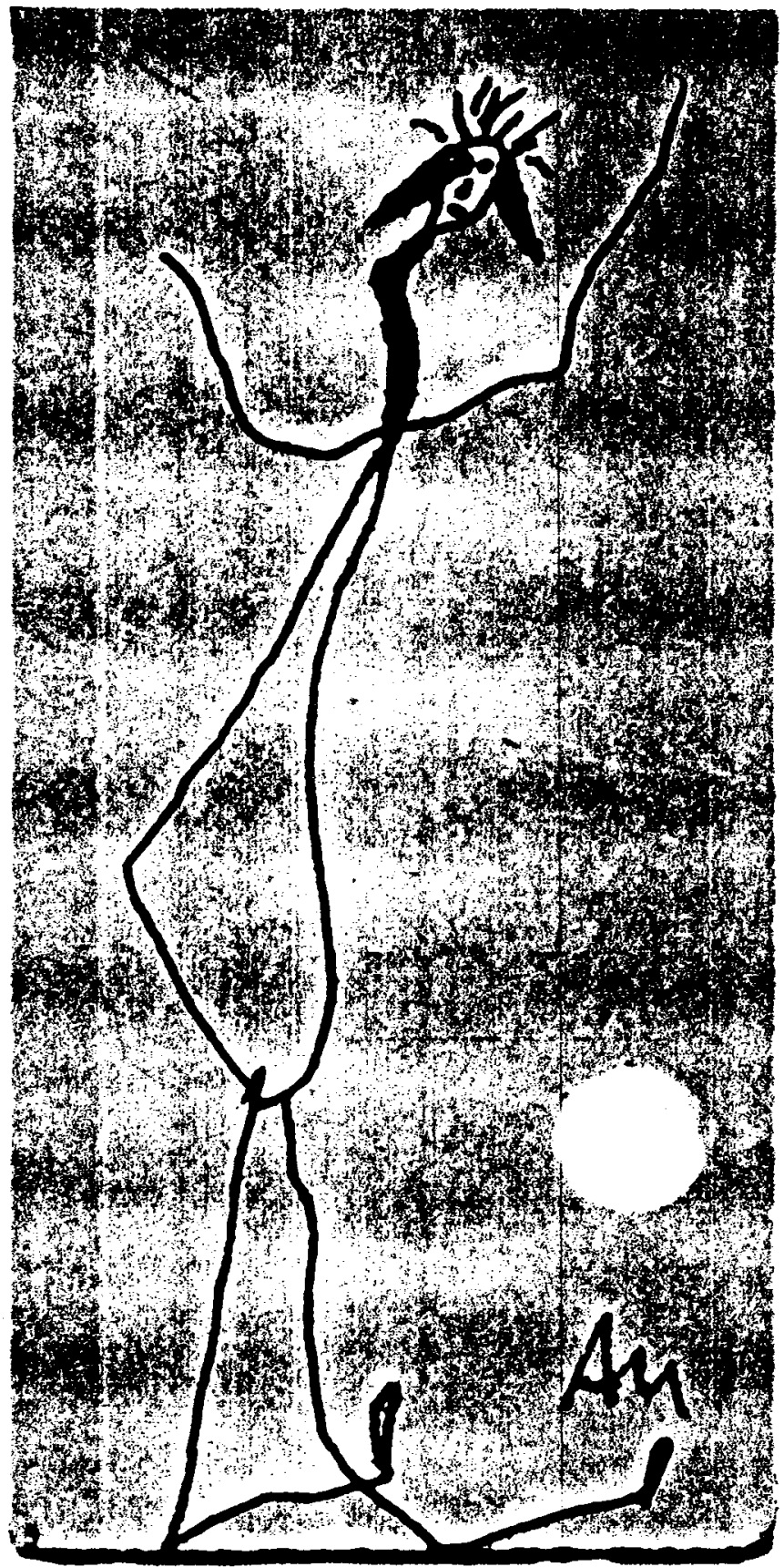

\title{
Adam Nidzgorski
}

